\title{
EXPANSION OF SOME SPECIES OF THE FRINGILLIDAE FAMILY IN THE ALGERIAN NORTHERN SAHARA
}

\author{
Abdelwahab Chedad ${ }^{1,2 *}$, Djamel Bendjoudi ${ }^{3}$, Omar Guezoul ${ }^{2,4}$ \\ ${ }^{1}$ University Kasdi Merbah, Department of Biological Sciences, Ouargla, Algeria, \\ ${ }^{2}$ Laboratory of Saharan Bio-ressources: Preservation and Valorisation, Ouargla, Algeria, \\ ${ }^{3}$ University of Blida, Faculty of sciences of the nature and of the life, \\ Laboratory of Biotechnology, Environment and Health, Algeria \\ ${ }^{4}$ University Kasdi Merbah, Department of Agricultural Sciences, \\ Faculty of Nature Sciences and Life, Ouargla, Algeria
}

\begin{abstract}
Fringillidae are a large family of the order Passeriformes where 07 species have been mentioned in Ghardaïa, north of the Algerian northern Sahara. Range mapping and phenological status was studied between 2017 and 2020 and based on monthly sampling using the method Progressive Frequency Sampling (EFP) throughout the territory of the Ghardaïa region. From seven species that have been reported, four species have wintering phenological status (Hawfinch Coccothraustes coccothraustes, Common Linnet linaria cannabina, Eurasian Siskin Spinus spinus and European Greenfinch Chloris chloris), two species (Trumpeter Finch Bucanetes Githagineus and European Serin Serinus serinus) have a sequentially phenological resident breeder and summer-migrant status; for Brambling Fringilla montifringilla, the status is not yet identified. The winter, summer or accidental observations of some species of the family Fringillidae in southern Algeria including the region of Ghardaïa considered as a form of expansion from North to South, where the latter, probably caused by several factors. At the national level two species are protected by Algerian law $N^{\circ} 12-235$ (Coccothraustes coccothraustes, Serinus serinus) and internationally all species have the least concern status according to the IUCN Red List, on the other hand, according to the Berne convention, six species listed on annex II and only one species (Fringilla montifringilla) listed on annex III.
\end{abstract}

Keywords: Algeria, Expansion, Fringillidae, migration, sedentarization.

\section{INTRODUCTION}

Algeria, which is part of the Western Palearctic, is bordered to the North by the Mediterranean Sea and to the South by the countries of the Sahel. This country is known for its great climatic diversity (subtropical, Mediterranean, semi-arid and arid) (Stevenson et al., 1988; Samraoui and Belair, 1998), by its geographical location, with all these characteristics that allow it to enjoy an important role in Biological Diversity (faunistic and Floristic), ecological, genetic, landscape and also cultural. (Chedad, com pers.). Wild animals are not randomly dispersed on land; each species appear in the habitat to which it is adapted, given the availability of water, food resources, available shelters and climatic factors. Indeed, the distribution area of a species results from the adequacy of environmental factors to its ecological requirements (Rolland, 1994). The northern Sahara, with a million $\mathrm{km}^{2}$, presents itself as a transition zone between the Mediterranean steppes of North Africa 
and the central Sahara. The rainfall to which the northern Sahara is subjected is between 50 and 100 $\mathrm{mm}$, (Le Houérou, 1990). Its climate is characterized in particular by low and irregular rainfall, and by pronounced thermal amplitudes between day and night and between months (Doumandji and Doumandji-Mitiche, 1994). The Fringillidae is a large family of the order Passeriformes where 11 species have been mentioned in Algeria, 10 species cited by Shirihai and Svensson (2018). These include the Common Chaffinch Fringilla coelebs, the Brambling Fringilla montifringilla, the European Serin Serinus serinus, the European Greenfinch Chloris chloris, the European Goldfinch Carduelis carduelis, the Eurasian Siskin Spinus spinus, the Common Linnet Linaria cannabina, the Red Crossbill Loxia curvirostra, the Trumpeter Finch Bucanetes githagineus, the Hawfinch Coccothraustes coccothraustes and a new species observed in Tamanrasset, the White-rumped Seedeater Crithagra leucopygia (Maghrebornitho 2020). This study aims to highlight the mapping of new observation sites in the Ghardaïa region and to study the phenological status of some species of the Fringillidae family.

\section{MATERIALS AND METHODS}

The present study took place basically in the Ghardaïa region, where this region is located in the central part of the northern Algerian Sahara (Heim De Balsac and Mayaud, 1962). It is part of the Saharan bioclimatic stage, characterized by very low and irregular annual precipitation.

For the monitoring of the population of the Fringillidae, the mapping of the range of some species of this family and defining the phenological status of each of them, we adopted the method of Progressive Frequency Sampling (EFP). It stems from the (IPA) method (Blondel, 1975), which this technique has already been used by several authors in Algeria (Moali, 1999; Bendjoudi et al., 2013; Farhi, 2014; Souttou et al., 2018; Chedad et al., 2020).

In our case, the surveys are carried out during the period from 2017 to 2020, when the Observer remains motionless is mentioned all the species of the family Fringillidae, visually or acoustically contacted in an imaginary circle of $100 \mathrm{~m}$ in diameter. The recorded species will be noted in the absence / presence, not forgetting to mention the abundance of each species and for each station visited throughout the study region (Ochando, 1988; Fonderflick, 2006).

The protection status of bird species has been assessed at the national level in relation to Executive Decree No. 12-235 of 24 May 2012 establishing the list of protected non-domestic animal species and at the international level, we have based ourselves on two agreements: the IUCN Red List (UICN 2020) and the Berne Convention (AFS, 2007). Finally, we mapped and updated geographic distribution maps to new locations detected outside its known range (BirdLife International) using software (ArcGIS version 10.2.2 for Desktop: Esriß).

\section{RESULTS AND DISCUSSIONS}

During the study period, seven species of the family Fringillidae were reported in Ghardaiia, out of the 11 nationally reported species. Of these, four species have wintering phenological status (Hawfinch, Common Linnet, Eurasian Siskin, and European Greenfinch), two species (Trumpeter Finch and European Serin) have sequential phenological status sedentary breeding and summermigrant, finally the Northern Finch that its status remains not yet identified (Table 1.).

\section{A- Hawfinch Coccothraustes coccothraustes}

Only three individuals were recorded in North Ghardaïa in the Noumérate green band, during a five-month period from December 2017 to April 2018. This species has the status of unregulated 
winter visitor (Figure 1A and 2A). In Algeria, there exists subspecies C. c. buvryi, 1862 (Shirihai and Svensson, 2018), its phenological status is resident breeder and winter visitor, of which the area of its distribution is from the far north of the country: Aurès, Constantinois, El Kala, northern slopes of the Tell Atlas (Akfadou), Babor, Mountains, upland cedarwood of the Djurdjura where it is rare, Algiers region, Ouarsenis, Tlemcen Mountains [Heim De Balsac and Mayaud (1962), Vielliard (1978), Chalabi et al. (1985), Moali (1990)] In Isenmann and Moali (2000). According to recent research (BirdLife International, 2017; Shirihai and Svensson, 2018), the Hawfinch is found in northern Algeria including all along the coast, the Tellien Atlas, the northern part of the Highlands and the Aurès Mountains. In Ghardaïa, our sighting is considered new to Algeria's northern Sahara.

Table 1. List of species of the family Fringillidae recorded in the Ghardaïa region

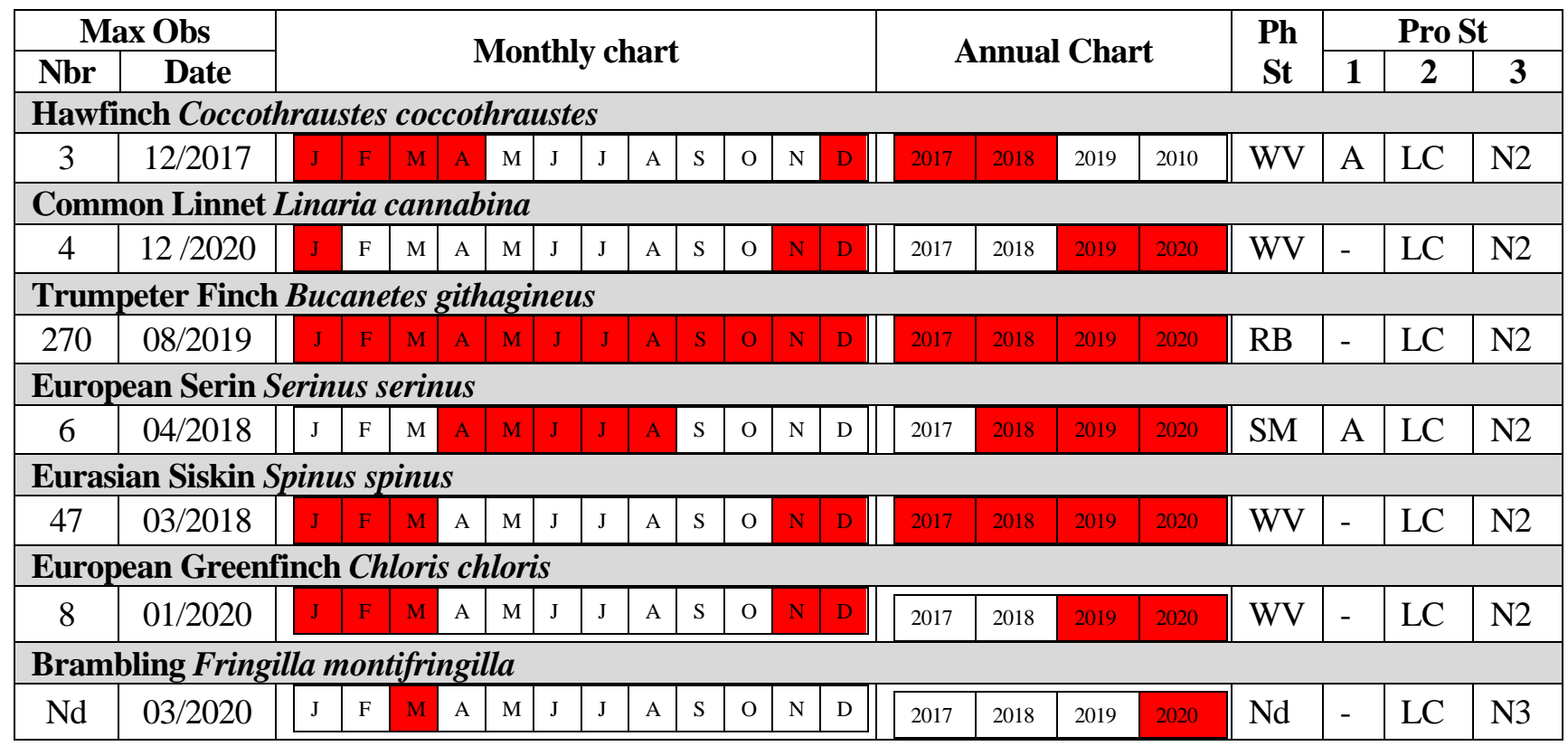

Max Obs: Maximum observed; Nbr: Number; St Ph: Phenological status [RB: Resident Breeder, WV: Winter Visitor, SM: Summer-migrant, Nd: Not definite]. St Pro: Protection status [1(A): Algerian law (N¹2-235); 2 (IUCN Red List): LC = Least concern; 3(N) Berne Convention: 2 = Annex 2; 3 = Annex 3.

\section{B- Common Linnet Linaria cannabina}

This species have been recorded during the last two years 2019 and 2020, in two different sites, in open environments at Noumérate and the other at the former palm grove of Ghardaïa with a maximum of four individuals observed. The Common Linnet has a winter visitor status (Figure 1B). In Algeria, there exists subspecies L. c. mediterranea (Tschusi, 1903) (Shirihai and Svensson, 2018), its phenological status is resident breeder and winter visitor. It nests from the coast south to the Saharan Atlas (absent however from Ain Sefra), Djelfa and the Aurès, with winter visitor reach the Central Sahara at Beni Abbès, Biskra, El Goléa, Ghardaïa, Ouargla, Temassinine et Timimoun [Heim De Balsac and Mayaud (1962), Dupuy (1966), Brehme et al. (1994)] In Isenmann and Moali (2000). Selon les publications récentes: BirdLife International, (2018) and Shirihai and Svensson, (2018), the Common Linnet keeps the same range, except for the observations mentioned in the Sahara at a new site in Illizi nord. Our sighting is considered recent in Ghardaïa. 


\section{C- Trumpeter Finch Bucanetes githagineus}

It is a species that characterize semi-desert and desert regions, including the Ghardaïa region. It is often observed in groups in the Rocky and Stony deserts, in wetlands, near water points, and sometimes in urban fabrics and green stripes. In Ghardaïa, the Trumpeter Finch a resident breeder species, reported only in the north of the region whose the maximum number is recorded in July 2019 with 270 individuals observed in the rocky plains of the Kef Doukhane wetland (Figure 1G and 2E). In Algeria, there exists the subspecies B. g. zedlitzi (Neumann, 1907); its phenological status is resident breeder, inhabiting rock biotopes throughout the Sahara [Isenmann and Moali, (2000); BirdLife International, (2019); Shirihai and Svensson, (2018)].

\section{D- European Serin Serinus serinus}

It is a species that frequents the region during the breeding period, where the latter is not yet confirmed. The European Serin is observed every year from April to August in the Green Band of Noumérate; this species appreciates especially the grains of Casuarina. A maximum of six individuals are reported in May 2018. The European Serin bears non-breeding summer-migrant status (Figure 1C and 2b). In Algeria, the phenological status of this is resident breeder and winter visitor, widespread breeding species in the whole Mediterranean zone of Algeria, up to the open upland Cedarwood (2000-2150 m a.s.l.) as well as the northernmost oases (Ain Sefra, Laghouat, Messaad et Biskra), with ancient winter observations made at Beni Abbès [Heim De Balsac and Mayaud (1962), Vielliard (1978), Burnier (1979), Dupuy (1966)] In Isenmann and Moali (2000). According to recent publications of BirdLife International, (2018) and Shirihai and Svensson, (2018), the range of European Serin extends from the Mediterranean to the south of the Saharan Atlas and the north of the Saharan platform. This is considered a new sighting in the Ghardaia region.

\section{E- Eurasian Siskin Spinus spinus}

It is a species that winters every year in the Ghardaiia region, arrives in November and leaves the site towards the end of March. The maximum number recorded in the region is 47 individuals observed precisely in the Noumerate green band. Other mention of the presence of the Eurasian Siskin is reported in Ouargla in December 2017 and November 2018. As with European Serin, Eurasian Siskin appreciates Casuarina grains (Figure 1D and 2C).In Algeria, its phenological status is winter visitor, this species is observed in several regions: Hammam-Meskoutin, Frenda, Tlemcen, Skikda, Tigzirt, Algiers, Oran, Mont de Tiaret, Petit kabylie, Ghardaïa, El Goléa [Bayn (1948); Snow (1952) ; Kerautret (1967) ; Heim De Balsac and Mayaud (1962)] In Isenmann and Moali (2000). According to recent publications of BirdLife International, (2017) and Shirihai and Svensson, (2018), the Eurasian Siskin is located only along the Algerian coast, this present observation is considered recent and new in the region of Ghardaïa and Ouargla.

\section{F- European Greenfinch Chloris chloris}

This species have been recorded during the last two years (2019 and 2020), north of Ghardaïa in open environments near the body of water. A maximum of eight individuals of the European Greenfinch was reported in the wetland of Oued El Bir. This species has a winter visitor status. This species bears winter visitor status (Figure 1E and 2D). In Algeria, there exists the subspecies $C$. c.voousi Roselaar, 1993 (Shirihai and Svensson, 2018), which its phenological status is resident breeder and winter visitor, widespread breeding from the coast to the northernmost oases as: 


\section{Current Trends in Natural Sciences}

Vol. 9, Issue 18, pp. 92-99, 2020

https://doi.org/10.47068/ctns.2020.v9i18.013

Current Trends in Natural Sciences (on-line)

ISSN: 2284-953X

Current Trends in Natural Sciences (CD-Rom)

ISSN: 2284-9521

ISSN-L: 2284-9521

ISSN-L: 2284-9521

Djurdjura, Aurès, Djelfa, Messad, Laghouat, the Ksour Mountains, Ain Sefra and Beni Abbès... [Heim De Balsac and Mayaud (1962); Daly and Daly (1975)] In Isenmann and Moali (2000); BirdLife International, (2018) and Shirihai and Svensson (2018). Our observation is considered a first mention in the Ghardaïa region.

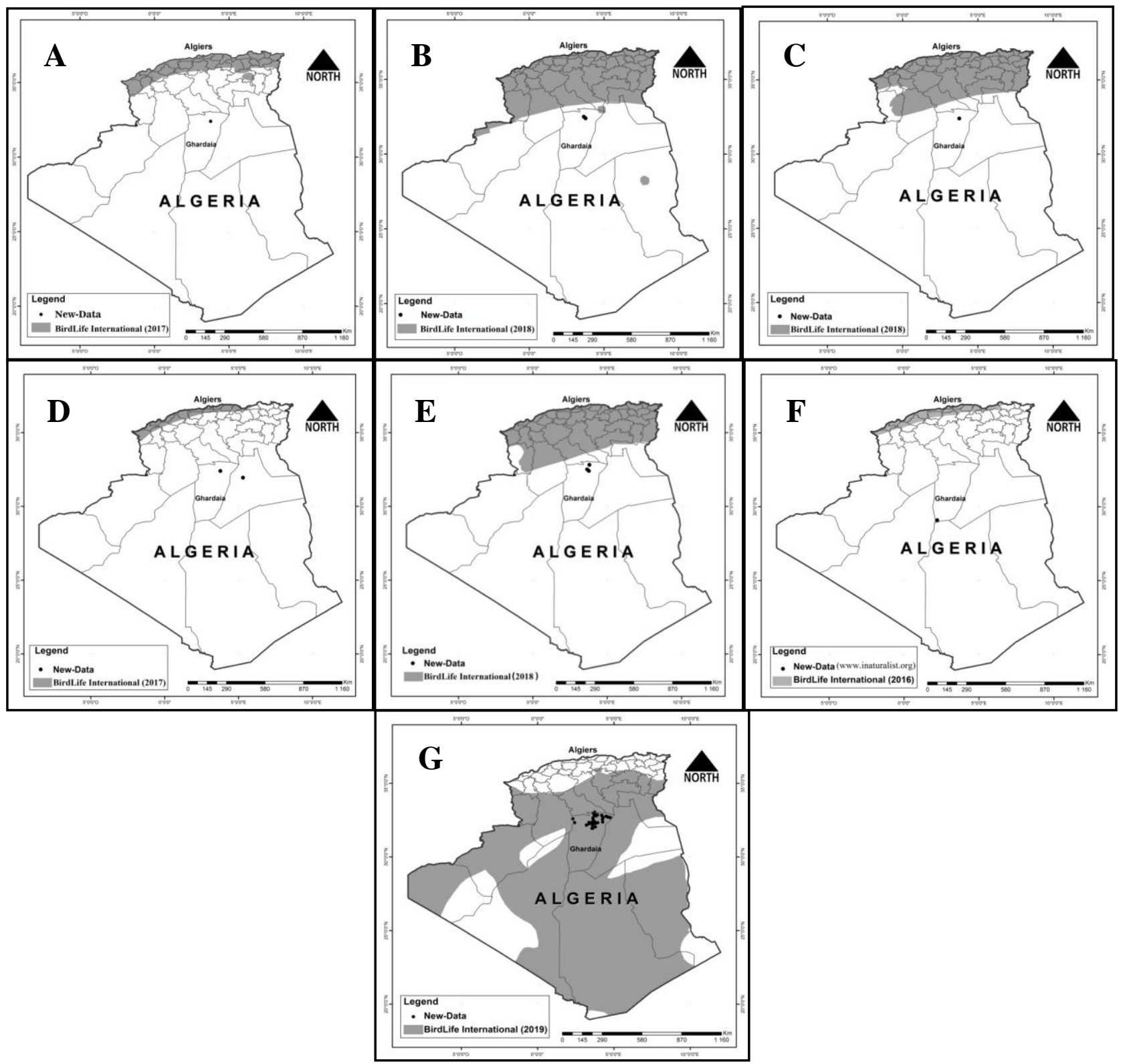

Figure 1. New observations of some species of the family Fringillidae in the Algerian northern Sahara.
A: Hawfinch Coccothraustes coccothraustes.
B: Common Linnet Linaria cannabina.
C: European Serin Serinus serinus.
D: Eurasian Siskin Spinus spinus.
E: European Greenfinch Chloris chloris.
F: Brambling Fringilla montifringilla.
G: Trumpeter Finch Bucanetes githagineus. 
Current Trends in Natural Sciences

Vol. 9, Issue 18, pp. 92-99, 2020

https://doi.org/10.47068/ctns.2020.v9i18.013

Current Trends in Natural Sciences (on-line) ISSN: 2284-953X

ISSN-L: 2284-9521
Current Trends in Natural Sciences (CD-Rom)

ISSN: $2284-9521$

ISSN-L: 2284-9521

\section{G- Brambling Fringilla montifringilla}

Only one individual has been reported in the extreme south of Ghardaia next to a sewage discharge (www.inaturalist.org), the phenological status is not recognized yet and probably it is an accidental visitor or a misplaced individual (Figure 1F). In Algeria, the phenological status of Brambling is winter visitor, it is represented by a small number that colonize the north of the country between November and March / April and exceptionally reported in Beni Abbès in the Sahara [(Heim De Balsac and Mayaud (1962), Dupuy and Johnson (1967)] In Heim De Balsac and Mayaud (1962). According to recent publications: BirdLife International, (2017) and Shirihai and Svensson (2018), the Brambling is located only along the Algerian coastline.

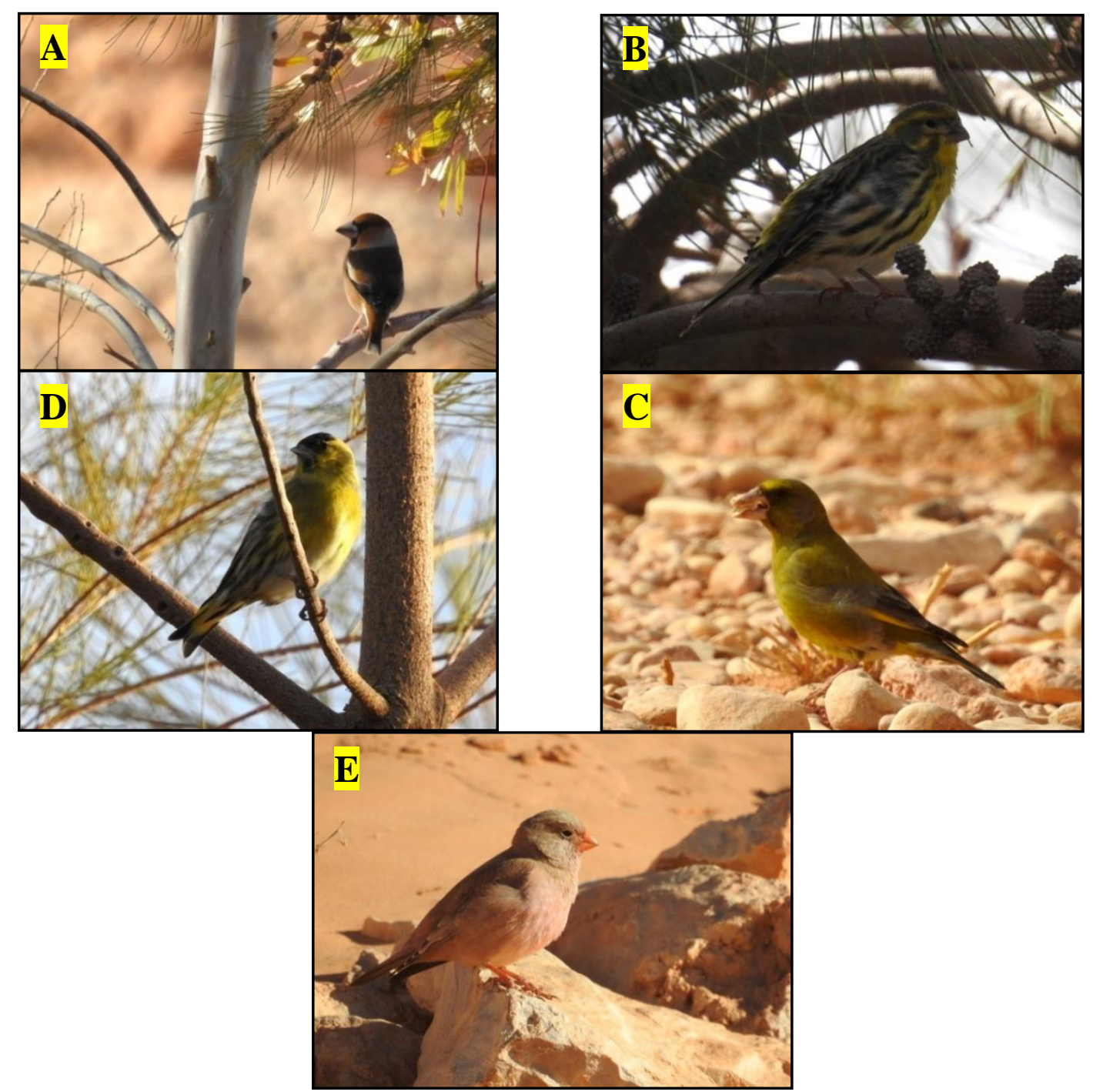

Figure 2. Some species of Fringillidae photographed in the Algerian northern Sahara.

A: Hawfinch Coccothraustes coccothraustes, Noumérate Green Zone, Ghardaüa, Algeria 13/02/2018 @ A. Chedad.

B: European Serin Serinus serinus, Noumérate Green Zone, Ghardaïa, Algeria 06/04/2018 @ A. Chedad.

C: Eurasian Siskin Spinus spinus, Noumérate Green Zone, Ghardaïa, Algeria 08/11/2018 @ A. Chedad.

D: European Greenfinch Chloris chloris, Wetland of Oued El Bir, Ghardaïa, Algeria 21/01/2020 (C) A. Chedad.

E: Trumpeter Finch Bucanetes githagineus, Wetland of Kef Doukhane, Ghardaïa, Algeria 12/01/2019 @ A. Chedad. 
In southern Algeria, particularly the Ghardaïa region, winter, summer or accidental observations of some species of Fringillids are considered as a form of expansion from the north to the South. Several factors seem to be the cause of this expansion: in the north by climate change, urban extensions, fires, intensive exploitation of Natural Resources, different forms of pollution; in the South by extensions of agricultural areas and the creation of strips and green spaces.

Nationally, two species of fringillidés are protected by Algerian law $\mathrm{N}^{\circ}: 12-235$ to know Coccothraustes coccothraustes, Serinus serinus). Internationally all species have the least concern status according to the IUCN Red List. Finally, according to the Berne convention, six species listed on Annex II concern strictly protected wildlife species and only one species (Fringilla montifringilla) listed in Annex III which concerns protected species.

\section{CONCLUSIONS}

In the northern Sahara, especially the Ghardaïa region, which contains a significant fauna and floristic diversity, where birds represent a large part of this diversity, it uses this region as an essential stopover site, as well as an important wintering and breeding district. The new data obtained now so far on the family Fringillidae, are considered a new and preliminary and this could pave the way for further research for about other bird families. In the same sense, periodic monitoring throughout the territory of Ghardaïa and the surrounding areas are ongoing, in order to make an update on the list of avifauna, mapped the range and fixed the phenological status of each species.

\section{ACKNOWLEDGEMENTS}

This work is part of the preparation of a doctoral thesis in Environmental Science at Kasdi Merbah University in Ouargla (Algeria). First of all, we would like to thank the authorities of the Directorate-General for forests (Forest conservation, Ghardaïa) for making it much facilitated our work on the ground. We also thank the members of the national network of Algerian birdwatchers (RNOOA), especially Ms. Oulmane K., Mezzi M., Horo A., Bendoui L., Ben Abderrahmane A. Ben Ahmed Z., Bendjedidi O., Hadj Mohamed T. for their support and support on the ground.

\section{REFERENCES}

AFS (2007). Convention relative à la conservation de la vie sauvage et du milieu naturel de l'Europe [Convention on the conservation of European wildlife and natural environment]. Site Web des autorités fédérales suisses, Texte original $\mathrm{N}^{\circ}$ (0.455), 68 p. http://www.admin.ch/ch/f/rs/i4/0.455.fr.pdf

Bendjoudi, D., Chenchouni, H., Doumandji, S., Voisin, J.F. (2013). Bird species diversity of the Mitidja Plain (Northern Algeria) with emphasis on the dynamics of invasive and expanding species. Acrocephalus, 34(156-157), $13-26$. https://doi.org/10.2478/acro-2013-0002

BirdLife International. 2016. Fringilla montifringilla. The IUCN Red List of Threatened Species 2016: e.T22720041A88203665. https://dx.doi.org/10.2305/IUCN.UK.20163.RLTS.T22720041A88203665.en. Downloaded on 19 September 2020.

BirdLife International. 2017. Coccothraustes coccothraustes (amended version of 2016 assessment). The IUCN Red List of Threatened Species 2017: e.T22720681A111132393. https://dx.doi.org/10.2305/IUCN.UK.20171.RLTS.T22720681A111132393.en. Downloaded on 19 September 2020.

BirdLife International. 2017. Spinus spinus (amended version of 2016 assessment). The IUCN Red List of Threatened Species 2017: e.T22720354A111126041. https://dx.doi.org/10.2305/IUCN.UK.20171.RLTS.T22720354A111126041.en. Downloaded on 19 September 2020.

BirdLife International. 2018. Chloris chloris. The IUCN Red List of Threatened Species 2018: e.T22720330A132000123. https://dx.doi.org/10.2305/IUCN.UK.20182.RLTS.T22720330A132000123.en. Downloaded on 19 September 2020. 
BirdLife International. 2018. Linaria cannabina.The IUCN Red List of Threatened Species 2018: e.T22720441A132139778. https://dx.doi.org/10.2305/IUCN.UK.20182.RLTS.T22720441A132139778.en. Downloaded on 19 September 2020.

BirdLife International. 2018. Serinus serinus. The IUCN Red List of Threatened Species 2018: e.T22720049A132136209. https://dx.doi.org/10.2305/IUCN.UK.20182.RLTS.T22720049A132136209.en. Downloaded on 19 September 2020.

BirdLife International. 2019. Bucanetes githagineus (amended version of 2017 assessment). The IUCN Red List of Threatened Species 2019: $\quad$ e.T22720513A155479195. https://dx.doi.org/10.2305/IUCN.UK.20193.RLTS.T22720513A155479195.en. Downloaded on 20 September 2020.

Blondel, J. (1975). L'analyse des peuplements d'oiseaux - éléments d'un diagnostic écologique. La méthode des échantillonnages fréquentiels progressifs (E.F.P) [Analysis of bird stands-elements of an ecological diagnosis. The method of progressive frequency sampling (E. F. P )]. Rev. Ecol. (Terre et Vie), 29(4), 533-589.

Chedad, A., Bendjoudi, D. and Guezoul, O. (2020). New data on the wintering and sedentary life of the European turtle dove Streptopelia turtur in the Algerian Northern Sahara. Current Trends in Natural Sciences, 9 (17): 65-73. https://doi.org/10.47068/ctns.2020.v9i17.007

Doumandji, S.and Doumandji-Mitiche, B. (1994). Ornithologie appliquée à l'agronomie et à la sylviculture [Ornithology applied to agronomy and forestry]. Ed. Off. Pub. Univ. Alger, 124p.

Farhi, Y. (2014). Structure et dynamique de l'avifaune des milieux steppique et présahariens et phoencicoles des Ziban[Structure and dynamics of the avifauna of the steppe and pre-Saharan and phoencultural environments of the Ziban], Thèse de doctorat, Université Mohamed Khider, Biskra, 354P.

Fonderflick, J. (2006). Suivi de la faune : méthodes de dénombrement des oiseaux. Aten, 83, 1-7.

Heim de Balsac (H.) and Mayaud (N.) 1962. Contribution à l'Ornithologie du Sahara Central et du Sud Algérien [Contribution to the Ornithology of the central Sahara and southern Algeria], Ed., Imprimerie. Le Typo-litho, Alger, 127.

Isenmann, P. and Moali, A. (2000). Oiseaux d'Algérie [Birds of Algeria]. Ed. Société d'études ornithologiques de France, Mus. nati. hist. natu., Paris, 336 p.

Le Houérou, H.N. (1990). Définition et limites bioclimatiques du Sahara. Science et changements planétaires [Definition and bioclimatic limits of the Sahara. Science and planetary change]. Sécheresse ; 1(4), 246-259.

MaghrebOrnitho (2020). White-rumped Seedeater (Serin à croupion blanc) Crithagra leucopygia: first for Algeria and Western Palearctic, https://www.magornitho.org/2020/01/first-white-rumped-seedeater-algeria/ (consulté 29 Juin 2020).

Moali, A. (1999). Déterminisme écologique de la répartition des oiseaux le long d'un transect altitudinal en Kabylie (Algérie) [Ecological determinism of the distribution of birds along an altitudinal transect in Kabylie (Algeria)]). Thèse Doctorat d'état, Uni. M. Mammeri, Tizi Ouzou, 220p.

Ochando, B. (1988). Méthode d'inventaire et de dénombrement d'oiseaux en milieux forestiers. Application à l'Algérie [Method of inventory and enumeration of birds in forest environments. Application to Algeria]. Ann. Inst. Nati.Agro. El Harrache, 12(spécial), 47-59.

Rolland, D. (1994).- Oiseaux du Vercors et Rhône Alpes. http : alpeoiseaux.free.fr.

Samraoui, B., Bélair, G. (1998). Les zones humides de la Numidie orientale: bilan des connaissances et perspectives de gestion. [The wetlands of Eastern Numidia: knowledge assessment and management perspectives] Synthèse (numéro spécial), 4, $1-90$.

Shirihai, H. and Svensson, L. (2018). Handbook of Western Palearctic Birds: Passerines: Larks to Warblers. Vol. II. London, HELM Bloomsbury Publishing.

Souttou, K.., Ababsa, L., Abidi, F., Guezoul, O., Sekour, M., Doumandji, S. (2018). Composition et Structure Avifaunistique dans une Steppe Arborée de Pin d'Alep à Chêne Vert à Sehary Guebli (Djelfa, Algerie). Lebanese Science Journal, 19(1), 19-30.

Stevenson, A.C., Skinner, J., Hollis, G.E., Smart, M. (1988).- The El Kala national park and environs, Algeria. An ecological evaluation. Environ. Conservation, 15, 335-348.

UICN, (2020). The International Union for Conservation of Nature, IUCN Red list of Threatened Species, http://www.redlist.org/. 